\title{
PHRASEOLOGICAL EXPRESSIONS AND PROVERBS IN ALBANIAN FOLK'S DICTIONARY
}

\author{
KIMETE CANAJ
}

\begin{abstract}
:
The purpose of this paper is to make a proverb analyses between the various phraseological expressions that originate from different regions in Kosovo, Albania, Macedonia, and Montenegro. The aim of this research is morphonological and pragmatical analysis of the Albanian proverbs due to empirical and theoretical phraseological methodology. What motivated us to write this paper is the fact that a relatively high number of this proverbs are used in phraseological expressions, so they are important in the respective culture and tradition. Idiomatic language is human-centred, because human body, or nature serves as an important source of idioms or proverbs as they resonate with anyone, both physically and metaphorically. These proverbs and idioms may display the philosophy of the people speaking Albanian language and serves as a window into the Albanian culture and tradition. Proverbs create accurate images in the mind that draw the reader's or listener's attention. Proverbs are not only used as stylistic features but also as persuasive arguments reflecting a people's way of life, culture, and tradition.

Studying language makes one aware that proverbs provide insights into the linguistic situations of scientific creativity. Moreover, proverbs and phraseologies are incredibly diverse and enable students to understand the wide range of opportunities and expressions that the language offers.
\end{abstract}

\section{Keywords:}

Phraseological expressions, Albanian Proverbs, Albanian folk's dictionary, Proverbs,

JEL Classification: 129, 120, 121

\section{Authors:}

KIMETE CANAJ, University "Ukshin Hoti" Prizren, Kosovo, Email: kimete.canaj@uni-prizren.com

\section{Citation:}

KIMETE CANAJ (2021). Phraseological expressions and proverbs in Albanian folk's dictionary. International Journal of Teaching and Education, Vol. IX(2), pp. 1-13., 10.52950/TE.2021.9.2.001 


\section{Introduction}

This paper presents the phraseological expressions, respectively the proverbs from the "Folk Dictionary - with about 20,000 words" by Prof. Abdullah Zymberi, published in 2014 in Prishtina, who collected them in different Albanian regions: 1. "In some areas of Kosovo in the villages of Mazrek, Planeja, Mile and Gjonaj of Has, in Vërmica and Struzha of Prizren, in Bresana, Brezne, Buçe, Pllajnik, Zaplluzha in Opoja of Dragash, Ruhot, Kaliçan, Sudenica, Trubuhoc, Shushica and Great Jabllanica in the districts of Peja and Istog, in Kërnica and Budisalc of Klina, in Burojë of Skenderaj, in Bllaca and in Budakova of Suhareka, and Demjan in Has of Gjakova, in Ivaja and Glloboçica of Kaçanik; 2. In some Albanian areas of Macedonia in Përshevc of Tetovo, in Nerez of Skopje, in Gradec of Gostivar and in Ostrec and Kishava of Manasitir; 3. In some Albanian areas of Montenegro in Vuthaj, Doli and in Martinaj of Plava-Gucia ". (Zymberi 2014, 1).

He collected the proverbs from his pupils ${ }^{1}$ and students and during study visits in different Albanian areas, and he spoke a beautiful, clear and rich Albanian with synonyms, comparisons and vernacular proverbs. He was very attentive to every word he heard with his special devotion to the Albanian language and its unedited vernacular lexicon. Zymberi explored the comparisons, the logic and figurativeness elaborated by the people. Accuracy was his pristine virtue.

He was an avid researcher of the rich vocabulary and rich verbal and grammatical forms of the Albanian language. In his dictionary, he collected rare folk proverbs from different Albanian territories thus preventing the dust of oblivion falling upon them, e.g.

(1) (a) Take the bitter with the sweet. (Kojë), p. 8

(b) A fool uttereth all his mind. (Mar-Krojë) p. 81

(c) Greed is a bottomless pit. (Ftj-Krajë), p. 87

(d) The tongue is sharper than any sword (Ftj-Krajë). P. 92

(e) It takes two to make a quarrel, but only one to end it. (Ftj- Krajë) p.97

This is his most important dictionary among his three published folk dictionaries. It includes his 40-year work in vernacular proverbs and expressions. He devoted his life to teaching and to the study of Albanian language in general. He used vernacular expressions in each of his works and was always applauded even in cases when the dictionary included curses and folk games. I will commence with the author's own expression: "The folk dictionary would not see the light of publication if it were not for my students and friends, whose help I will never forget, and blessed be they for life! (Zymberaj 2014, 393)

The methodology used by the author in this dictionary as well as the criteria of structural-didactic composition is based on the Dictionary of Albanian Language ${ }^{2}$ (Thomai, J. Samari, M.... 2006),

\footnotetext{
${ }^{1}$ His student Ilir Shaqiri states: " To meet Professor Abdullah, to sit with him even for a coffee was like you were becoming the knight on the white wings of a lush horse heading into the depths of centuries, all over the corners of the homeland, inseparable. It seemed as if you were hearing voices from two thousand years ago, a pure and sophisticated Albanian, rinsed on the petrographic marble slab of a fountain that never drains out. He did not talk about the ordinary everyday life because he was exemplary in his devotion to the Albanian language, to its unedited lexicon, to its rare words which are fading every day generation after generation"

https://telegrafi.com/abdullah-zymberi-qemtues-pashoq-shqipes-burimore/ (9.01.2020)

${ }^{2}$ Dictionary of the Albanian language with 48000 words, Academy of Sciences of Albania, Tirana, 2006
} 
but the main principle of the author when compiling the folk dictionary was that every word and expression in this dictionary is compared with the Dictionary of Albanian Language and is listed in the Folk Dictionary only if it was missing in the aforementioned dictionary. As Zymberi points out in his interview in Telegrafi on 11.05.2015: "Folk expressions live in the vernacular dialects, and are words deriving from Albanian, but which are not included in the Dictionary of Albanian Language, and only localisms, when conventionalized, become part of the general lexicon of Albanian. ... There is everything out there, there are lexemes formed with prefix-suffix processes which are novel to the lexical system of Albanian "3.

This paper has only selected proverbs from the folk dictionary which are not in the Dictionary of the Albanian Language, and which serve to enrich the language and culture of the Albanian people. Zymberi has collected these proverbs and expressions from different areas during the process of teaching and study visits.

Zymberi, as a pedagogue, lexicographer, lexicologist, dialectologist, albanologist and scholar of Albanian language emphasizes that "There, in the deep mountainous areas still lives the unwritten word of our beautiful language. We find nothing in areas where roads are all asphalt, we have to go deeper. To dig deeper in the ancient streams, in the sound of swords, in the bedrock of castles, in the mouths of generations, in the trunks of oaks and in the dust of the woolen plis; I search and search for you, oh word of my land! - Professor Zymberi used to recite to his students, while advising them to deal with the important things and avoid the insignificant"4

Using expressions, phrases and proverbs is one of the most attractive ways of enriching the vocabulary, as Shakespeare himself emphasizes: "Learning idioms is the best way to improve your vocabulary" William Shakespeare.

This paper deals with the use of proverbs and the figurative, comparative meaning of words and expressions utilized in different areas where Zymberi has collected them. Therefore, this paper indirectly contributes to proverbs not being forgotten by the Albanian society.

The proverbs, curses and folk games which represent the customary life of Albanians over the centuries have been published for the first time in this folk dictionary. Proverbs were collected in the Albanian highlands, in places where "the whispering of the huts is felt, where we have seen and investigated how the Albanian word 'breathes', whether that of the shepherd with the crutch in his hand, or that in the dusty plis of our farmer "5

Meaning, functional value and possible use of the phraseology. Proverbs may be used in form of warning, persuasion, argument, affirmation, consolation, counsel, correction, or statement. Their characterization, explanation, description, reasoning and summary has been explored in studies such as the ones by (Burger 2003,103, Mieder, 2012, 2014; Nolte \& Mieder 2012; Mieder \& Nolte 2018; Mieder 2018;Röchrich 2003).

Phraseological units and proverbs absorb the values of the time they pertain to. The problem of understanding phraseological units is related to the possibility of increasing our global linguistic knowledge in a diachronic aspect that encompasses the relationship between language and society.

\footnotetext{
3 Interview of Prof. dr.Abdullah Zymberi by journalist Gazmend Kajtazi in Telegraf on 11.05.2015 https://telegrafi.com/prof-abdullah-zymberi-levruesi-i-leksikografise/ (8.01.2020)

${ }^{4}$ Yes there.

${ }^{5}($ Zymberi 2014, 1)
} 
The importance of proverbs should not be underestimated under any circumstances, as they can be used as a basis for prejudices and stereotypes of various kinds. Precisely for this reason, they are used repeatedly, especially in politics as (Röchrich 2003, 23) and (Ramadan 2015, 5) claim.

This paper will examine only the proverbs and no other phraseological units, since they will be discussed in other works.

\section{Proverbs in folk dictionary}

Many research studies show that proverbs are now used much less frequently in everyday life than in early times, and therefore this paper explores the selection of the proverbs from Zymberi's folk dictionary, some of which I have never heard before.

If we read the media and the political discourse carefully, we will encounter proverbs, but this time borrowed from other languages or taken from the Bible and classical authors. They are often included in media texts or used intentionally in press to give emphasis to titles. Ads also use proverbs since they convey images that reflect complex factors in a more simpler way (Mieder $2012,8)$. Proverbs create accurate images in the mind that draw the reader's or listener's attention. Proverbs are not only used as stylistic features but also as persuasive arguments reflecting a people's way of life, culture and tradition.

Studying language makes one aware that proverbs provide insights into the linguistic situations of scientific creativity. Moreover, proverbs and phraseologies are incredibly diverse and enable students to understand the wide range of opportunities and expressions that the language offers.

Vocabulary enrichment is done through the use of phrases and proverbs that are often utilized and applied specifically. In this paper, 60 proverbs have been summarized from the Folk Dictionary, and they have been classified alphabetically in Annex 1. The reason for this alphabetical classification is grounded on the fact that the retention of proverbs in the mental lexicon is done according to a certain structure or order, so that they can be recalled at the right moment when we want to clarify or emphasize something or describe a certain situation.

Analysis of proverbs from Zymberi's Folk Dictionary

The proverbs are classified into three categories: word repetition, phrase comparison and a general morpho-syntactic analysis of proverbs.

\subsection{Word repetition}

The repetitive word reinforces the meaning of the expression.

A fool uttereth all his mind. (Mar-Krajë) p. 81

It takes two to make a quarrel, but only one to end it. (Ftj- Krajë) p.97

Many a little makes a mickle. (Ftj-Krajë) p.99

Hold the thief, hold the thief!-I am holding him, but he does not let go (Hot) p. 170

\subsection{Phrase comparison}

He goes where the wind blows. (Ftuj-Krajë), p. 8. 
Take the bitter with the sweet. (Kojë), p. 8

Soft and fair goes far. (Ru-Pejë), p.21

You reap what you sow/As is the gardener so is the garden. (Ru-Pejë), p. 52

The next day as an old sack. (Marë-Krajë) p. 57

Words cut deeper than swords (Ftj-Krojë), p. 79

Long hair but a short brain. (Mar- Krojë) p. 80

Greed is a bottomless pit. (Ftj-Krajë), p. 87

The tongue is sharper than any sword (Ftj-Krajë). P. 92

The more you give the more you receive. (Ftj-Krajë) p.147

Death is closer than the shirt. ((Ftj- Krajë) p. 169

May you take all my pains. (Kojë) p.169

Smiles before talking. (Ftj- Krajë). P. 169

Do as you would be done by. (Ftj-Krajë) p. 174

The dog that doesn't bark is like a sweet pepper. (Marë- Krajë), p. 275

Calm as the sea. (Ftj- Krajë) p. 276

Birds of a feather flock together. (Vërmi-Prizren) p.288

Two heads better than one. (Ftj-Krajë) p. 293

When single you are a gentleman, when you get old you are a dog. (Ftj-Krajë) p. 293

Different places, different customs. (Ftj- Krajë) p. 293

When the head does not work, the legs suffer. (K.eB.-Tuz) p. 335

It honours your household. (Ftj-Krajë) p. 335

The brave forgives, the coward revenges. (Grudë) p. 346

River stones remain, while water flows away. (K.B-Grudë) p.358

My son is my son till he gets him a wife, but my daughter's my daughter all the days of her life. (Ftj- Krajë) p.360 (a daughter-in-law can never replace a daughter)

Women are like wine! (Mar-Krojë) p. 360

Like seeks like. (Ftj- Krajë) p. 360

\section{Pure Albanian language, autochthonous Albanian, and linguistic feeling}

Phrases in proverbs can be classified into the following: verbal phrases, adjectival phrases, negation phrases or conditional phrase, but the important matter is that they express linguistic feelings and represent the vernacular culture through synonyms, comparisons and other stylistic figures. In some proverbs it is difficult to distinguish verbal, noun, and adjectival phrases, since the meaning of the phrase is conceived by two or more words. 


\subsection{Verbal and comparative phrases e.g.}

An excellent wife is the crown of her husband, but she who brings shame is like rottenness in his bones. (Ftj.- Krajë) p. 96

The more you give the more you receive. (Ftj-Krajë) p.147

You don't have to call your friends; you just visit them. (Ftj- Krajë) p. 181

Cut from the same cloth/The apple never falls far from the tree. (Mar-Krajë). p. 228

Work before play. (Ftj-Krajë), p. 234

You get what you deserve. (Mart-Guci), p. 45

\subsection{Adjectival phrases}

A pretty maid for a handsome man. (Ftj-Krajë) p. 304

Long hair but a short brain. (Mar- Krojë) p. 80

\subsection{Noun phrases}

The better the land, the better the crops. (Ru-Pejë), p. 52

The tongue is sharper than any sword (Ftj-Krajë). P. 92

Long hair but a short brain. (Mar- Krojë) p. 80

3.4 Negation phrases (pa, mos, s', as-as, nuk)

Greed is a bottomless pit. (Ftj-Krajë), p. 87

Man proposes, God disposes. (Mar-Krajë), p.45

It takes two to make a quarrel, but only one to end it.

Don't praise your furnace when the house is cold. (Opojë) p. 160

Don't stick your nose where it doesn't belong. (Kodër - Tuz). P. 184

Don't count your chickens before they are hatched. (Ftj- Kraj). P. 184

If there were no millet grains, a mother wouldn't ask her son to give it a try (Ftj- Krajë)

Do good and good will follow you. (Hot) p. 192

Stubborn as a mule. (K.cB.-Tuz) p. 193

Man is the head but woman turns it (Ftj- Krajë). P. 209

A gun without bullets makes the same noise. ((Marë- Krajë), p. 273.

Man proposes, God disposes. (Mar-Krajë) p. 293

Beauty draws with a single hair.(Ftj-Krajë) p.304

May it snow, may it rain, but we wish that winter never came! (Kodër -Tuz) p. 307 
Time flies. (Ftj-Krajë) p.314

\subsection{Conditional phrases}

The more you give the more you receive. (Ftj-Krajë) p.147

God knows what's on his/her mind. (Mar-Krajë), p. 147

He who is waiting for someone else's bowl often dines late (Kodër- Tuz) p. 182

Don't stick your nose where it doesn't belong. (Kodër - Tuz). P. 184

\section{Conclusion}

Folk wisdom words vary depending on the time and the health rules, but it is remarkable how these picturesque expressions survive, so that even today they are still used in certain or specific situations.

Zymberi's folk dictionary is an added value to the Albanian language which contributes for proverbs to be known, understood, reinforced and used by young people, so as they are not covered by the dust of oblivion.

This dictionary deals with the entire vernacular lexicon of the aforementioned territories in a lexical model way, but according to phonological features with diacritical marks [:] for long vowels (e.g. do: $r$, pre :, pa: $s$, shpi :) as well as [ $\left.{ }^{\wedge}\right]$ in nasal vowels $a$ and $e$ which represents the nasalization of vowels (e.g. Alb. N,bân mi:r, gjen n'shpe:ll pa fun. (Hot) (Eng. Do good and good will follow you p. 192), and also according to the peculiarities of phraseology, with structural 'petrification' and idiomatics of lexical meanings of vernacularexpressions through proverbs, folk songs, curses and blessings. The dictionary also provides a comprehensive and thorough elaboration of the meanings of words and folk phraseological units by shifting the focus to the emotional-expressive values, which are greater in folk rhetoric than in the synonymous words of the standard Albanian language.

The dictionary clearly defines the boundaries of the phraseological unit in Albanian as to where it starts and where it ends as a structure, and this is related to the prepositions or conjunctions, to the short pronoun forms (Soft and fair goes far; with open arms; to fill his head with...), to open and closed parts of phraseological units, to some grammatical categories such as article or number of nouns, to verb tense, and so forth (to direct something - to solve something; to banish or oust someone).

Proverbs are familiar, fixed sentences that express a rule of life or wisdom in a summarized form (Mieder 2014, 10).

Phraseology deals with the exploration of proverbs, as well as with the close connection of words

and with the figurative meaning of words and expressions. In a broader sense, phraseology includes many areas, such as idiomatic expressions, idioms, routine formulas, collections, truisms, empirical sentences, functional advertising structures, modeling, proverbs, blessings, curses, and so forth.

In order to enrich today's vocabulary, linguists should work harder not to discredit the words of the past, and thus with a rich vocabulary the thinking will be clearer. 
Proverbs are a blessing to schools. In addition to the fact that they provide material with certain rules and creativity, they also provide ingenuity and shine like stars in the heads and hearts of students. "A teacher who uses proverbs with dignity, thus holding a lesson of mental training, is much healthier in preserving language than through the hunger for grammar". (Wander KFW 1988, 13).

Proverbs convey powerful messages as a result of the long-life experience and the challenges and difficulties that people have faced during their life. To support this idea, our argument is grounded on the following four proverbs:

1. Words cut deeper than swords (Ftj-Krojë), p. 79

2. A fool uttereth all his mind. (Mar-Krojë) p. 81

3. The tongue is sharper than any sword (Ftj-Krajë). p. 92

4. Patient people live longer. (Kojë), p. 9

These four proverbs go through three periods and are not only a physical presence in this world, but also spiritual traces: ever-lasting education and endurance and survival of values for the current and future generation.

"Proverbs are often used to say something eloquently, in some cases to weigh the thoughts well, and to emphasize the tradition of the ancestors in the field of oral creativity. Proverbs can be used simply to make the conversation or dialogue more lively." (Ramadani 2015,10 )

The meaning of proverbs can be very different but it mostly contains life experience and knowledge in form of a folk wisdom or instruction, warning, rule or command. Proverbs are characterized by their situational variety, i.e., they often contain a generalization that is understandable and unrelated to a specific context or situation. As Burger states: "If you want to use a proverb, memorize it. This is a process that works similarly to the recalling of vocabulary, because here too, you have to recall the linguistic parts from memory. ${ }^{7}$

\section{Summary}

This paper sought to summarize proverbs from Zymberi's folk dictionary with about 20,000 words, which have a rich teaching potential. They are the bearers of the albanian national culture everything starts with the mother tongue - proverbs are the bridge to intercultural competence. Specific deviations from literal meaning make language more vivid. Proverbs mold the values and norms that apply to a certain culture and period of time. They contribute to overcoming the learning difficulties in spoken and written language today.

The illustration with some selected examples fills the gap of explanations and provides the vivid use of words and phraseological units in the vernacular language. The first and most important task of working on this dictionary has been to build a corpus of vernacular words and expressions with explanations and the region where they are used, and which have not been part of the Dictionary of the Albanian Language. This lexicon which enriches the vocabulary, and the Albanian language system can also be used to compile an all-folk Albanian dictionary that would summarize all the words, expressions, and folk phrases from all regions where the Albanian

\footnotetext{
${ }^{6}$ Ramadan 2015, 10 explains Albanian proverbs and compares them with Roman proverbs "What is learned in the cradle, is abandoned only in the grave "; "The deepest rivers make the smallest gurgling"; "Books are the immortality of the past and the eternity of the future."

7"Möchte man ein Sprichwort verwenden, erinnert man sich an es. This is a Vorgang der ähnlich as well as Vokabelanrufen function, so that even here the spicy Vertigteile from Gedächtnis abrufen muss "(Burger 2003, 40)
} 
language is spoken. Such a dictionary would be needed by writers, publicists, translators who learn the Albanian language, comparative linguists, even folklorists or psychologists who want to discover the folk mentality and ethnic culture which is historically conceived in phraseological structures.

To collect these words, phrases, proverbs, and folk games that are a real treasure of the people, Abdullah Zymberi passed through hundreds of Albanian villages, from Kraja, through different parts of Kosovo, to the district of Skopje, Tetova and to the Albanian villages of Kishava and Ostrec of Manastir, located near the border of Macedonia with Greece. His aim was to save from oblivion those few "old phrases" that are greatly needed in the Albanian dictionary. This work, in fact, was also a contribution to the strengthening of the Albanian national identity which has its foundation in Albanian language itself. The best thing would be to collect the vernacular lexicon of all Albanian-speaking regions to compile the folk dictionary. These proverbs are an evidence that language reflects the mentality of a nation.

Phraseological units absorb values of the ages in which it lives. The problem of understanding the meaning of a phraseological unit is linked with a possibility of increasing our knowledge about the world diachronically. The authors underline the importance of phraseological studies as it demonstrates the interrelation between the language and the society. The role of phraseological units as specific structures in forming vocabulary and linguacultural competence of students is very significant because they encapsulate a national, country's cultural outlook. Usage-based theories of language learning suggest that phraseology must be studied as a part of vocabulary. Teaching phraseology is a part of cultural approach in foreign teaching methodology and arranging vocabulary studying though structure of component meaning is linguistic approach.

\section{Annex 1. Proverbs - English in Abdullah Zymberi's folk dictionary, 2014}

1. What in the Sam Hill is that? Sam Hill is an euphemism for the devil here. (Kies-Tuz) p.8

2. He goes where the wind blows. (Ftuj-Krajë), p. 8.

3. Patient people live longer. (Kojë), p. 9

4. Take the bitter with the sweet. (Kojë), p. 21

5. Soft and fair goes far. (Ru-Pejë), p.21

6. Every mother with a daughter knows the pains of her daughter-in-law. (Ftj-Krajë) p. 40

7. You get what you deserve. (Mart-Guci), p. 45

8. Man proposes, God disposes. (Mar-Krajë), p.45

9. You reap what you sow/As is the gardener so is the garden. (Ru-Pejë), p. 52

10. The next day as an old sack. (Marë-Krajë) p. 57

11. You have to sit as a cat under the table. (Ftj.- Krajë), p. 66

12. It's not about what you say, it's about what you do. (Ru-Pejë) p. 69

13. The better is the cream that is hit by a girl. (Kojë) p. 70

14. Words cut deeper than swords (Ftj-Krojë), p. 79 
15. Long hair but a short brain. (Mar- Krojë) p. 80

16. A fool uttereth all his mind. (Mar-Krojë) p. 81

17. Greed is a bottomless pit. (Ftj-Krajë), p. 87

18. The tongue is sharper than any sword (Ftj-Krajë). p. 92

19. An excellent wife is the crown of her husband, but she who brings shame is like rottenness in his bones. (Ftj.- Krajë) p. 96

20. It takes two to make a quarrel, but only one to end it. (Ftj- Krajë) p.97

21. Many a little makes a mickle. (Ftj-Krajë) p.99

22. The more you give the more you receive. (Ftj-Krajë) p.147

23. God knows what's on his/her mind. (Mar-Krajë), p. 147

24. Don't praise your furnace when the house is cold. (Opojë) p. 160

25. Death is closer than the shirt. ((Ftj- Krajë) p. 169

26. May you take all my pains.(Kojë) p.169

27. Smiles before talking. (Ftj- Krajë). P. 169

28. Hold the thief, hold the thief!-I am holding him, but he does not let go. (Hot) p. 170

29. Do as you would be done by. (Ftj- Krajë) p. 174

30. Know yourself before judging others (Ftj-Krajë) (Ftj- Krajë) p. 174

31. You don't have to call your friends, just visit them. (Ftj- Krajë) p. 181

32. He who is waiting for someone else's bowl often dines late (Kodër- Tuz) p. 182

33. Don't stick your nose where it doesn't belong. (Kodër - Tuz). P. 184

34. Don't count your chickens before they are hatched. (Ftj- Kraj). P. 184

35. If there were no millet grains, a mother wouldn't ask her son to give it a try. (Ftj- Krajë)

36. Do good and good will follow you. (Hot) p. 192

37. Stubborn as a mule. (K.cB.-Tuz) p. 193

38. Man is the head but woman turns it. (ftj- Krajë). p. 209

39. Nothing better than a country bride and Kelmeni cheese (Mill- Aramal)

40. Cut from the same cloth/The apple never falls far from the tree. (Mar-Krajë). p. 228

41. Work before play. (Ftj-Krajë), p. 234

42. A gun without bullets makes the same noise. ((Marë- Krajë), p. 273

43. The dog that doesn't bark is like sweet peppers. (Marë- Krajë), p. 275.

44. As calm as the sea. (Ftj- Krajë) p. 276

45. Birds of a feather flock together. (Vërmi-Prizren)p.288

46. Two heads better than one. (Ftj-Krajë) p. 293 
47. When single you are a gentleman, when you get old you are a dog. (Ftj-Krajë) p. 293

48. Different places, different customs. (Ftj- Krajë) p. 293

49. Man proposes, God disposes. (Mar-Krajë) p. 293

50. Beauty draws with a single hair.(Ftj-Krajë) p.304

51. A pretty maid for a handsome man. (Ftj-Krajë) p. 304

52. May it snow, may it rain, but we wish that winter never came! (Kodër -Tuz) p. 307

53. Time flies. (Ftj-Krajë) p.314

54. When the head does not work, the legs suffer. (K.eB.-Tuz) p. 335

55. It honors your household (Ftj-Krajë) p. 335

56. The brave forgives, the coward revenges. (Grudë) p. 346

57. River stones remain, while water flows away. (K.B-Grudë) p.358

58. My son is my son till he gets him a wife, but my daughter's my daughter all the days of her life. (Ftj- Krajë) p.360 (a daughter-in-law can never replace a daughter)

59. Women are like wine! (Mar-Krojë) p. 360

60. Like seeks like. (Ftj- Krajë) p. 360 (Das ist Topf wie Deckel),

\section{Annex 2 Proverbs - Albanian in Abdullah Zymberi's folk dictionary, 2014}

1. Ai që kjo:ft tr:t. Eufemizëm për djallin (Kies-Tuz) fq.8

2. Aj shkon kah t'fryn veri. (Ftuj-Krajë), fq. 8.

3. T,arnuemit e t,duruemit rrno:jn shum. (Kojë), fq. 9

4. N't'amel i pari, n't tharbt i mrami. (Kojë), fq. 21

5. Me t'amel e han dynjë:n e me t'idht s'munesh me dal as tu dera e oborrit. (Ru-Pejë), fq.21

6. Çdo na:n qi ka vajz, ja di nuses. (Ftj-Krajë) fq. 40

7. Çka nje:Il zogu, ta çon Zot. (Mart-Guci), fq. 45

8. Çka tho:t dhija e ardhija mos e tha:sht Perënija. (Mar-Krajë), fq.45

9. Çysh â ara, bin fara. (Ru-Pejë), fq. 52

10. Di:t n'tjetër si thes i vjetër (Marë-Krajë) fq. 57

11. Duhet me ne:jt si mica nën stol. (Ftj.- Krajë), fq. 66

12. Nuk asht me t'thanun' po me t'dhanun (Ru-Pejë) fq. 69

13. E mirë është maza qi e godet vajza.(Kojë) fq. 70

14. Fjala është ma e ra:n se topi (Ftj-Krojë), fq. 79

15. Flok g-jatat, mëne pakta. (Mar- Krojë) fq. 80

16. Fol çka t'fol, e diçka ruej për veti. (Mar-Krojë) fq. 81 
17. Fyti isht shpe:Il pa fun. (Ftj-Krajë), fq. 87

18. Gjuha isht helmi i dynja:s (Ftj-Krajë). Fq. 92

19. Grueja ta nxi:n derën, por edhe ta zba:rdh derën. (Ftj.- Krajë) fq. 96

20. Grusht mi grusht s'maron kurrë. (Ftj- Krajë) fq.97

21. Gur mi gur bahet kalaja. (Ftj-Krajë) fq.99

22. Ku ha miku, e shton Zoti. (Ftj-Krajë) fq.147

23. Ku me dit çka bluen krymi. (Mar-Krajë), fq. 147

24. Livdimi n'qiell maxhja pa miell. (Opojë) fq. 160

25. Ma afër se kmisha e shtatit a deka. ((Ftj- Krajë) fq. 169

26. Ma marrsh ta:n t'keqen e shtratit.(Kojë) fq.169

27. Ma pa'r qeshet se flet. (Ftj- Krajë). Fq. 169

28. Mae hajnin Mae hajnin!-Unë po e ma, po aj s'um Ishon. (Hot) fq. 170

29. Mat për veti se s'gabon kurr. (Ftj-Krajë) fq. 174

30. Mat për veti, e fol për tjetrin (Ftj -Krajë) (Ftj- Krajë) fq. 174

31. Mikun s'ke nevo:j me e thi:rr, po shkoj. (Ftj- Krajë) fq. 181

32. Mjer pshesht që e presin qumshtin e huaj (Kodër- Tuz) fq. 182

33. Mos e qyej hudën, aty ku nuk vyje. (Kodër - Tuz). Fq. 184

34. Mos kjaj para vaktit. (Ftj- Kraj). Fq. 184

35. Mos me kje:n kokrra e melit, nuk çon nana dja:I pej venit. (Ftj- Krajë)

36. Nbân mi:r, gjen n'shpell pa fun. (Hot) fq. 192

37. As me i pri: nuk vjen, as me i gra:h nuk shkon. (K.cB.-Tuz) fq. 193

38. Nuk i nigojm gra:t, po baj:jm çka tho:n (ftj- Krajë). Fq. 209

39. Nuse veni e djath Kelmeni (Mill- Aramal)

40. Pëlhu:rs kqyrja anën e vajzës nanën. (Mar-Krajë). fq. 228

41. Për pu:n gjithmo:n u meno:ft. (Ftj-Krajë), fq. 234

42. Pushka pa fyshek tu:t dy ve:t. ((Marë- Krajë), fq. 273.

43. Qeni qi s'leh, si speci qi s'djeg (Marë- Krajë), fq. 275.

44. Rahat si deti. (Ftj- Krajë) fq. 276

45. U rroklli:kapaki e xhet tenxheren. (Vërmi-Prizren)fq.288

46. Sa gjin aq menje. (Ftj-Krajë) fq. 293

47. Sa je beqar je zotni, kur të plakesh je qen. (Ftj-Krajë) fq. 293

48. Sa vene aq adete. (Ftj- Krajë) fq. 293

49. Si tho:t dhija e ardhija mos e tha:ft Perënija. (Mar-Krajë) fq. 293 
50. Syni i çkruem s'ka të paguem.(Ftj-Krajë) fq.304

51. Syni i zi për djal: t'ri. (Ftj-Krajë) fq. 304

52. Shi e bo:r ra:ft e dimën mos na a:rdht! (Kodër -Tuz) fq. 307

53. Shkon e s'kthehet ma. (Ftj-Krajë) fq.314

54. T'mjerat kâ:m n'krye t'ma:rr. (K.eB.-Tuz) fq. 335

55. Ta zba:rdh derën. (Ftj-Krajë) fq. 335

56. Trimi t'fal, e i marri t'vret. (Grudë) fq. 346

57. Ujt shkon, po zalli metet. (K.B-Grudë) fq.358

58. Vajza jeme gato:ft n'dimën, e nusja e jeme gato:ft n'verë. (Ftj- Krajë) fq.360 (Për vajzën me lehtë)

59. Vajza është si vêna! (Mar-Krojë) fq. 360

60. Vegshi kapakun gjen. (Ftj- Krajë) fq. 360 (Das ist Topf wie Deckel),

\section{References}

Burger, Harald. 2010. Phraseologie. Eine Einführung am Beispiel des Deutschen. 4., neu bearbeitete Aufl. Berlin.

Hermann-Winter, Renate. 2018. Sprichwörter und Redensarten von der Insel Rügen. Historische Sammlungen aus Altefähr von 1832. Rostock: Hinstorff.

Mieder, Wolfgang. 2018. In Proverbiis Veritas. Sprachkulturelle, literarische und politische Studien. Münster, New York: Waxmann.

Mieder, Wolfgang. 2014. „Wer andern ein Grube gräbt..."- Sprichwörtliches aus der Bibel in moderner Literatur, Medien und Karikaturen. Wien: Praesens Verlag.

Mieder, Wolfgang \& Nolte, Andreas. 2018. Ein Schwert hält das andere in der Scheide. Otto von Bismarcks sprichwörtliche Rhetorik. Würzburg: Königshausen\& Neumann.

Nolte, Andreas \& Mieder, Wolfgang. 2012. „Zu meiner Hölle will ich den Weg mit guten Worten pflastern“ - Friedrich Nietzsches sprichwörtliche Sprache. Hildesheim/Zürich/New York: Georg Olms Verlag.

Ramadani, Ramadan H. 2015. Comparative aspects of Albanian proverbs with those of Romance languages. Prizren

Röhrich, Lutz. 1991, 1992. Das große Lexikon der sprichwörtlichen Redensarten. 3 Bde. Freiburg

Zymberi, Avdullah (2014): Folk Dictionary. With about 20,000 Words. Prishtina. GrafoBeni. Wander KFW 1988,2010 